\title{
PERBEDAAN PENGARUH LATIHAN PEREGANGAN SAS-BALISTIK DENGAN PNF-BALISTIK TERHADAP FLEKSI BILITAS TRUNKUS LANSIA
}

\author{
Kayun Sari (alm), Sukadarwanto, S.Th. Susilowati \\ Politeknik Kesehatan Surakarta Jurusan Fisioterapi
}

\begin{abstract}
Elderly, SAS, Trunks, PNF. Elderly will be experienced by everyone who was blessed with longevity. Change is an advanced stage of development of life with a decrease in the body's ability to adapt to environmental stress. Decreased ability can be inhibited with the exercises. There are three stretches used is SAS, ballistic and PNF. This study is an experimental research design with two group pre test - post test design. The study was conducted at the Hospice Dharma Bhakti Surakarta in June-July 2007. The gauge trunk flexibility is Sit and Reach Test. 18 subjects showed flexibility can improve significantly after being treated SAS or PNF exercises,
\end{abstract}

Keywords: Elderly, SAS, Trunks, PNF.

Abstrak: Lansia, SAS, Trunkus, PNF. Lanjut usia akan dialami semua orang yang dikaruniai umur panjang. Perubahan itu merupakan tahapan lanjutan dari perkembangan hidup dengan terjadinya penurunan kemampuan tubuh dalam beradaptasi terhadap stres lingkungan. Penurunan kemampuan itu dapat dihambat dengan latihan-latihan peregangan. Ada tiga peregangan yang digunakan yaitu SAS, Ballistik, dan PNF. Penelitian ini merupakan penelitian Eksperimental dengan rancangan two group pre test - post test design. Penelitian dilakukan di Panti Wreda Dharma Bakti Kota Surakarta pada bulan Juni - Juli 2007. Alat pengukur fleksibilitas trunkus Sit and Reach Test. 18 Subjek menunjukkan dapat meningkatkan fleksibilitas secara signifikan setelah mendapat perlakuan latihan SAS maupun PNF.

Kata Kunci: Lansia, SAS, Trunkus, PNF.

\section{PENDAHULUAN}

Kualitas fisik adalah salah satu aspek yang tidak boleh diabaikan dalam menjalankan aktivitas atau latihan. Beberapa unsur kemampuan fisik dasar yang perlu dikembangkan antara lain kekuatan, daya tahan, fleksibilitas atau kelenturan, kelincahan, keseimbangan, kecepatan, maupun koordinasi. Bagi orang tua yang bukan olahragawan, fleksibilitas dapat menunjang aktivitas kegiatan seharihari; sedangkan bagi olahragawan, fleksibilitas sangat dibutuhkan sebagai prasyarat menampilkan ketrampilan yang memerlukan gerak sendi luas. Pada lanjut usia terjadi banyak kemunduran, diantaranya unsur kemampuan fisik, misalnya kelenturan/ fleksibilitas.

Darmojo (2000), pembatasan lingkup gerak sendi terjadi pada lanjut usia akibat keketatan/ kekakuan otot dibandingkan sebagai akibat kontraktur sendi. Terbatasnya lingkup gerak sendi akan membatasi kelenturan/ fleksibilitas sehingga berakibat timbul keterbatasan aktivitas fungsional. Faktor yang mempengaruhi fleksibilitas yaitu tipe persendian, elastisitas otot, ligamen, 
bentuk tubuh, jenis kelamin, suhu otot, dan usia.

Lanjut usia adalah suatu kejadian yang pasti akan dialami oleh semua orang yang dikaruniai umur panjang. Lansia bukan suatu penyakit, tetapi merupakan tahap lanjut dari suatu proses kehidupan yang ditandai dengan penurunan kemampuan tubuh dalam beradaptasi terhadap stres lingkungan. Batasan usia lanjut, menurut World Health Organization (WHO) (Makmun, 1998) dikelompokkan dalam (1) middle age 45-59 tahun, (2) elderly 60-74 tahun, (3) old 75-90 tahun, (4) very old 91 tahun ke atas. Penelitian Kamso dkk. (1998) menyebutkan bahwa gambaran fungsi tubuh para lansia mengalami penurunan kekuatan $88 \%$, fungsi penglihatan $72 \%$, kelenturan tubuh $64 \%$, daya ingat $61 \%$, pendengaran $67 \%$, dan bidang seksual $86 \%$.

Menurut Suharno (1993), latihan adalah kegiatan dalam memberi beban pada tubuh secara teratur, sistematis, berkesinambungan; sehingga dapat meningkatkan kemampuan di dalam melakukan kerja. Meningkatkan kemampuan yang maksimal dapat ditempuh dengan melakukan latihan fisik. Tujuan latihan menurut Harre (1982) adalah (1) mengembangkan kepribadian, (2) kondisioning dengan sasaran meningkatkan kekuatan (power), kecepatan, kekuatan, daya tahan, kelenturan, (3) meningkatkan teknik dan koordinasi gerak, (4) meningkatkan taktik serta mental.

William (1993), fleksibilitas adalah kemampuan berbagai sendi tubuh melalui luas gerak sendi secara penuh. Menurut Sajoto (1995) kelenturan adalah daya lentur dalam penyesuaian diri untuk segala aktivitas dengan penguluran tubuh yang luas.

Manfaat yang diperoleh dari fleksibilitas/ kelenturan otot adalah membantu otot untuk rileks, menghilangkan kekejangan otot, mengurangi potensi cidera (Lutan, 2000). Menurut Harno (1993), manfaat kelenturan yaitu (1) menghindari terjadinya cidera, (2) meningkatkan kelincahan, kecepatan, koordinasi, (3) membentuk sikap tubuh yang baik, (4) efektivitas dan efisiensi tenaga, (5) seni gerak tercermin indah dan enak dipandang.

Alters (1996) menjelaskan bahwa peregangan bermanfaat bila dilakukan dengan benar. Manfaat melakukan peregangan antara lain (1) meningkatkan kebugaran fisik, (2) mengurangi resiko cidera punggung, (3) meningkatkan rileksasi, (4) mengurangi resiko otot kram, (5) mengoptimalkan penampilan, (6) mengurangi nyeri otot. Kelenturan seseorang sangat tergantung pada beberapa faktor yaitu (1) elastisitas otot, ligamen, tendo, kapsul sendi, dan luas sempit ruang sendi; (2) tonus otot, tendo, ligamen; (3) suhu; (4) unsur kejiwaan, sedih, muram, senang, semangat; (5) umur dan jenis kelamin.

Otot rangka mempunyai dua jenis saraf penerima rangsang (reseptor) yaitu muscle spindle dikenal sebagai intra fussal, dan golgi tendon (GTO) yang terletak di tendon dikenal sebagai extra fussal. Muscle spindle berperan dalam perubahan panjang ukuran otot (meregang, mengkerut), mempengaruhi kecepatan perubahan panjang otot. GTO berperan dalam memberi isyarat terhadap kekenyalan maupun kekuatan otot.

Stretch reflex atau refleks meregang, terjadi bila peregangan 
berlangsung secara cepat, akan terjadi kontraksi otot secara refleks. Pada saat otot diregangkan, akan terjadi perubahan pada muscle spindle dan golgi tendon. Perubahan ini akan mengakibatkan terjadi pembakaran pada stretch reflex, sehingga terjadi kontraksi otot. Misal pada tendo patela, yang diketuk - ketuk dengan hamer akan terjadi refleks ekstensi lutut.

Bentuk - bentuk adaptasi dapat diperoleh dari aktivitas peregangan. Bila suatu otot diregangkan secara tiba - tiba, akan timbul stretch reflex. Selanjutnya otot yang diregang akan berkontraksi. Latihan peregangan dapat menstimulasi produksi dan penyimpanan bahan berupa jeli yaitu Glycoaminoglycans (GAGs), yang bersama air dan asam hyaluron melumasi serat - serat jaringan, akibatnya seratserat tersebut lebih licin.

Setiap melakukan peregangan akan berhubungan dengan proses pemanjangan. Latihan peregangan dapat dilakukan dalam berbagai macam cara tergantung pada tujuan yang ingin dicapat. Alters (1996) menjelaskan ada lima bentuk pergengan dasar yaitu statik, balistik, pasif, aktif, dan Propriocaptive Neuromusculair Fascilitation (PNF).

Setiap melakukan peregangan akan berhubungan dengan posisi tubuh bertahan atau tubuh tetap pada posisi semula tanpa berpindah tempat. Pada teknik ini otot diregang sampai titik terjauh kemudian bertahan pada posisi meregang.

Rushall et al (1990) menjelaskan bahwa ada tiga metode latihan peregangan yang sudah digunakan di dalam olah raga yaitu Slow Active Stretching (SAS), Proprioceptive Neuromusculair Fascilitation (PNF) dan Balistik. Peregangan $S A S$ termasuk juga dalam peregangan aktif yang dilakukan secara pelan - pelan. Prinsipnya hampir sama dengan peregangan statik.

Seseorang setelah dilahirkan, secara fisiologis akan menjadi tua. Dengan semakin bertambahnya usia, jaringan - jaringan maupun sel - sel tubuh akan semakin tua, sebagian mengalami degenerasi dan sebagian yang lain akan mati (Santrock, 1992).

1) Batasan usia lanjut.

WHO (Makmun,

mengelompokkan usia lanjut yaitu (1) midle age 45-59 tahun, (2) elderly 6074 tahun, (3) old 75-90 tahun, (4) very old 91 tahun ke atas. Dalam hal ini yang dimaksud dengan usia lanjut adalah seseorang yang telah berumur 60 tahun ke atas (elderly).

2) Proses menua.

Menurut Sutarto et al (1986) pada proses menua akan terjadi perubahan perubahan pada fisik, yang terdiri dari perubahan anatomik dan fisiologik. Perubahan - perubahan ini dapat dilihat seperti otot mengecil, kekuatan, fleksibilitas, keseimbangan, daya tahan, kecepatan reaksi, koordinasi gerakan, semua menurun. Alter (1996) menjelaskan beberapa perubahan fisik yang terjadi sehubungan dengan bertambahnya usia yaitu (1) bertambahnya timbunan kalsium, (2) kemudahan patah, (3) bertambahnya dehidrasi, (4) menurunnya kemampuan fisik, salah satunya adalah fleksibilitas. Fleksibilitas yang menurun dapat dihambat dengan melakukan latihan peregangnan sehingga dapat merangsang glycoaminoglycans, sebagai gel yang melumasi jaringan, sehingga tidak mudah terjadi kekakuan jaringan.

Semakin usia bertambah, khususnya pada usia lanjut, akan semakin menurun kemampuan fisiknya, sehingga pada usia lanjut ini jarang mereka 
melakukan aktivitas. Kurangnya mereka melakukan aktivitas semakin mempercepat proses penurunan terhadap kekuatan, daya tahan, keseimbangan, kecepatan reaksi, dan kelenturan / fleksibilitas. Fleksibilitas sangat penting dalam hubungannya dengan luas gerak sendi, maupun aktivitas sehari - hari. Agar fleksibilitas ini tidak cepat menurun, dapat dilakukan latihan - latihan peregangan secara teratur. Misalnya peregangan SAS, PNF, atau Balistik. Teregangnya otot akan merangsang Glyco Amnino Glycans (GAGs), semacam pelumas. Akibatnya otot menjadi lentur, tidak kaku. Untuk itu sangatlah penting bagi semua, khususnya para lansia untuk selalu aktif melakukan peregangan.

Penelitian ini mengembangkan kerangka konsep penelitian berdasarkan kajian teoritis sebagai berikut:

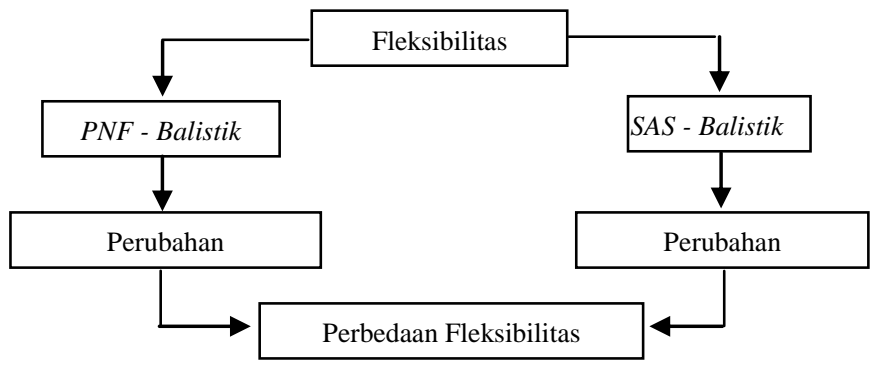

METODE PENELITIAN

Jenis penelitian ini termasuk Penelitian Eksperimental dengan menggunakan Rancangan Two Group Pre Test-Post Test Design.

RO1 ------------- X ------------------ O2

Keterangan:

O1 : Kelompok Pre Test peregangan PNF-Balistik

O2 : Kelompok Post Test peregangan PNF - Balistik

$\mathrm{X} \quad$ : Perlakuan
O3 : Kelompok Pre Test peregangan SAS-Balistik

O4 : Kelompok Post Test peregangan $S A S$ - Balistik

Lokasi penelitian adalah Panti

Wreda Dharma Bhakti Surakarta, dan waktu penelitian Juni-Juli 2007. Populasi penelitian adalah semua penghuni Panti Wreda Dharma Bhakti yang berusia $60-75$ tahun dan sudah tinggal di Panti Wreda minimal tiga bulan, mampu berkomunikasi, mampu duduk maupun berdiri sendiri atau bisa mandiri. Selain itu, kaki, lutut, lengan, leher, punggung, dapat ditekuk dan diluruskan.

Pengambilan sampel dilakukan dengan metode Match Subject Ordinary Pairing (MSOP). Dari populasi yang ada, yang memenuhi kriteria, kemudian diambil 36 orang, dipasangkan menjadi dua kelompok berdasarkan hasil pengukuran fleksibilitasnya. Dua kelompok selanjutnya diberikan perlakuan latihan fleksibilitas dengan $P N F$ - Balistik dan SAS - Balistik. Masing-masing kelompok berjumlah 18 orang subyek yang terdiri dari 9 orang laki-laki dan 9 orang perempuan. Penelitian ini menggunakan alat pengukur fleksibilitas trunkus Sit and Reach Test. Bahan yang lain adalah alat tulis untuk mencatat hasil pengukuran fleksibilitas trunkus, leaflet tentang latihan fleksibilitas trunkus dengan PNF - Balistik dan SAS - Balistik.

\begin{tabular}{ccc}
\hline Jauhnya Raihan $(\mathrm{cm})$ & Skor & Kategori \\
\hline$>19$ & 5 & Sangat Baik \\
$11.5-19$ & 4 & Baik \\
$-1.5-11.5$ & 3 & Cukup \\
$-6.5-(-1.5)$ & 2 & Sedang \\
$<-6.5$ & 1 & Kurang \\
\hline Pengumpulan & data & dilakukan
\end{tabular}

dalam dua tahap yaitu tahap pertama peneliti mencatat identitas lansia yang telah ditetapkan sebagai sampel meliputi nama, usia, alamat, jenis kelamin, tinggi 
badan, dan berat badan. Kemudian dilakukan pengukuran awal (pre test) terhadap sampel tentang kelenturan/ fleksibilitasnya dengan menggunakan alat Sit and Reach test. Data yang telah dikumpulkan kemudian direkapitulasi, lalu dimasukkan program SPSS ver 11.00. Data tersebut kemudian dianalisis secara bertingkat sebagai berikut di bawah ini. Data Karakteristik Penelitian

\begin{tabular}{|c|c|c|c|c|c|}
\hline Karakteristik & $\mathrm{N}$ & Min & Mak & $\begin{array}{l}\text { Rata- } \\
\text { rata }\end{array}$ & $\begin{array}{c}\text { Simpangan } \\
\text { Baku }\end{array}$ \\
\hline Umur & 36 & 60 & 75 & 68 & 4.644 \\
\hline Berat badan & & 33 & 70 & 46.33 & 7.859 \\
\hline $\begin{array}{l}\text { Tinggi } \\
\text { badan }\end{array}$ & & 135 & 166 & 151.72 & 9.631 \\
\hline $\begin{array}{l}\text { Fleksibilitas } \\
\text { sebelum } \\
\text { perlakuan }\end{array}$ & & 1 & 24 & 8 & 5.329 \\
\hline $\begin{array}{l}\text { Fleksibilitas } \\
\text { setelah } \\
\text { perlakuan }\end{array}$ & & 2 & 27 & 10.31 & 5.115 \\
\hline
\end{tabular}

\section{HASIL PENELITIAN}

Pada saat dilakukan pengumpulan data diperoleh 36 subyek penelitian yang memenuhi kriteria penerimaan, yaitu 18 subyek laki-laki dan 18 subyek perempuan, kisaran umur 60-75 tahun, dengan kriteria bersedia mengikuti program penelitian dan setelah diperiksa memenuhi syarat untuk dijadikan subyek penelitian. Pembagian kelompok menjadi dua secara purposive (MSOP) yaitu (1) kelompok yang mendapat perlakuan $P N F$ - Balistik sebanyak 18 subyek, dan (2) kelompok yang mendapatkan perlakuan SAS - Balistik sebanyak 18 subyek.

Perhitungan dengan $t-$ test menunjukkan bahwa fleksibilitas sebelum dan sesudah latihan dengan menggunakan SAS - Balistik didapatkan nilai rerata fleksibilitas 8.72 (sebelum perlakuan) menjadi 11.11 (sesudah perlakuan). Hasil perhitungan signifikansi dua ekor (two tail) $p=0.00$. Dengan demikian, karena $p$
$<0.05$ maka dinyatakan ada peningkatan fleksibilitas secara bermakna pada latihan penguluran metode $S A S$ - Balistik pada lansia. Dengan degree of freedom 17 didapatkan $t$ - hitung setelah perlakuan 8.609 dan $t$ - tabel pada $\alpha 0.05=2.11$, berarti $t$ - hitung lebih besar daripada $t-$ tabel. Hal tersebut menunjukkan bahwa ada peningkatan fleksibilitas secara bermakna pada latihan penguluran metode SAS - Balistik pada lansia.

Perhitungan dengan $t-$ test menunjukkan bahwa fleksibilitas sesudah latihan dengan $P N F$ - Balistik dan sessudah latihan dengan SAS - Balistik, didapatkan nilai rerata fleksibilitas $9.50 \pm$ 4.743 (sebelum perlakuan) dan $11.11 \pm$ 5.476 (sesudah perlakuan). Hasil perhitungan signifikansi dua ekor (two tail) $p=0.352$. Dengan demikian karena $p$ $>0.05$ maka antra latihan penguluran metode PNF - Balistik dengan SAS Balistik pada lansia tidak menunjukkan perbedaan bermakna. Dengan degree of freedom 35 didapatkan $t$ - hitung -0.943 dan $t$ - tabel pada $\alpha 0.05=2.042$, berarti $t$ - hitung lebih kecil daripada $t$ - tabel. Hal ini menunjukkan bahwa tidak ada perebedaan yang bermakna antara latihan penguluran metode $P N F$ - Balistik dengan SAS - Balistik pada lansia. Oleh karena keduanya tidak ada ada yang lebih baik, maka kedua metode tersebut dapat dipergunakan untuk metode latihan peningkatan flaksibilitas pada lansia.

\section{PEMBAHASAN}

Perubahan biologis dan fisiologis pada lansia disebabkan perubahan gaya hidup dan keadaan kapasitasnya. Perubahan tersebut dapat mempengaruhi fleksibilitas, kekuatan otot, perubahan postur, perubahan pola jalan, dan dapat 
mengakibatkan timbulnya nyeri (Lewis, 1196; Darmojo, 1999).

Fleksibilitas subyek setelah perlakuan $11.11 \pm$ 5.47. Perhitungan dengan $t$ - test menunjukkan bahwa $p=$ 0.00 , dan karena $p<0.05$ maka latihan SAS - Balistik dapat meningkatkan fleksibilitas secara bermakna. Hal tersebut menunjukkan bahwa jenis latihan ini dapat direkomendasikan untuk dipergunakan pada peningkatan fleksibilitas lansia, baik laki-laki maupun perempuan.

Latihan penguluran secara aktif, secara tidak langsung juga menjadikan lansia lebih aktif melakukan olah raga atau latihan, sehingga lansia lebih aktif dalam beraktivitas fisik, mengurangi kebiasaan lansia dalam inaktivitas. Walaupun fleksibilitas hanya merupakan salah satu komponen dalam aktivitas, namun pengaruh fleksibilitas menjadi sangat besar terhadap aktivitas lansia itu sendiri.

Penuaan juga mempengaruhi
jaringan kartilago, menjadi lebih
menguning, sehingga elastisitas dan kompresi pada sendi menjadi menurun. Bantalan sendi pada tulang belakang menjadi menipis yang menyebabkan jarak antara ruas tulang menjadi lebih dekat. Hal itu dapat menjadikan penurunan tinggi badan 0.5 inci setiap 20 tahun setelah usia 40 tahun (Howker, 1994).

Pada kebanyakan lansia yang tidak aktif, dapat terjadi penurunan luas gerak sendi pada beberapa sendi, antara lain sendi gelang bahu dan sendi hip (Lewis, 1995). Sehubungan dengan hal itu maka latihan atau olah raga / latihan penguluran secara aktif, menjadi salah satu pilihan untuk meningkatkan fleksibilitas maupun kapasitas fisik secara umum. Latihan dapat dilakukan sendiri - sendiri maupun berkelompok.

\section{KESIMPULAN DAN SARAN}

Kesimpulan pada penelitian ini adalah PNF - Balistik berpengaruh terhadap fleksibilitas trunkus lansia. Latihan SAS - Balistik berpengaruh terhadap fleksibilitas trunkus lansia juga terverifikasi. Hasil perhitungan dengan $t-$ test menunjukkan bahwa pengaruh latihan SAS - Balistik terhadap fleksibilitas trunkus lansia sebesar $p=0.00$, dan karena $p<0.05$ maka hipotesis penelitian ini yang menyatakan ada peningkatan fleksibilitas secara bermakna pada latihan penguluran metode SAS - Balistik pada lansia terverifikasi. Hal tersebut juga menunjukkan bahwa ada peningkatan fleksibilitas secara bermakna pada latihan penguluran metode SAS - Balistik pada lansia.

Pengaruh PNF - Balistik dan SAS - Balistik, tidak menunjukkan perbedaan terhadap fleksibilitas trunkus lansia. Perhitungan statistik menunjukkan $p=$ 0.352, dan karena $p>0.05$ maka keduanya tidak ada yang lebih baik dalam mempengaruhi fleksibilitas trunkus lansia. Begitu juga hasil $t$ - hitung didapatkan nilai -0.943, dengan degree of freedom 17 maka $t$ - tabel pada $\alpha 0.05=2.11$. Dalam hal ini, karena $t$ - hitung lebih kecil daripada $t$ - tabel, maka Hipotesis $\mathrm{Ha}$ pada penelitian ditolak, dan Hipotesis Ho diterima. Perlu adanya penelitian lebih lanjut dalam masalah ini, dengan sampel lebih banyak dan di daerah lebih luas. Juga perlu diteliti dampak dari latihan jenis ini terhadap resiko cidera dan resiko peningkatan tekanan darah pada lansia. 


\section{DAFTAR RUJUKAN}

Alter, M.J., 1996; Science of Flexibility; second edition, Published Human Kinetica, USA.

Alter M.J., 1997; 300 Teknik Peregangan (alih bahasa Jamal Khalib); P.T. Raja Grafindo Persada, Jakarta.

Brent, R. and Frank, P., 1990; Training for Sports and Fitness; Mac Millan Company, Melbourne.

Clarkson, H.M., 1989; Musculo Sceletal Assesment Joint Range of Motion and Manual; William \& Walkins, USA.

Darmojo, B. R., 2000; Ilmu Kesehatan Usia Lanjut; Edisi ke-2, Penerbit FK UI, Jakarta.

Depkes RI, 1990; Pedoman Pembinaan Usia Lanjut; Edisi ke-3, Direktorat Bina Kesehatan Keluarga, Ditjenbinkesmas, Jakarta.

Foxs, M. L. \& Steven, J., 1998; Physiological Basic for Exercises and Sports; The Mc Graw - Hill Company.

Gardiner, M.D., 1980; The Principle of Exercise Therapy; Third Edition, London.

Hadi, S., 1995; Metodologi Riset; Jilid 3, Penerbit Andi Offset, Jakarta.

Hadinoto, S., 1993; Gangguan Neurologi pada Usia Lanjut; Semarang.

Harsono, 1988; Coaching dan Aspekaspek Psikologis dalam Coaching; Ditjen Pendidikan Tinggi Lembaga Pendidikan Tenaga Kependidikan, Jakarta.

Haywood, K.M., 1986; Life Span Motor Development; Human Kinetic Publisher, Illinois.

Johnson, B.L. and Jack, 1986; Practical Measurements for Evaluation in Physical Education; Publishing Company, USA.
Lutan, R., 2003; Menuju Sehat Bugar; Ditjen Olah Raga, Depdiknas, jakarta.

Suharno, H.P., 1993; Metodologi Pelatihan; IKIP, Yogyakarta.

Sujana, 1995; Desain dan Analisis Eksperimen; Tarsito, Bandung.

Tudor, B.O., 1993; Theory and Metodology Training; Publishing Company, IOWA.

Uram, P., 1986; Latihan Peregangan (alih bahasa Iskandar dan engkos Kosasih); Pressindo, Bandung.

Wahab, A.A., 1999; The Effect of Aging on Muscular Strength and Functional Ability of Health; Saudi Arabia. 